\title{
Oxygen Reduction by Sol Derived [Co, N, C, O]-Based Catalysts for Use in Proton Exchange Membrane Fuel Cells
}

\author{
Aislinn H. C. Sirk, ${ }^{a}$ Stephen A. Campbell, ${ }^{\mathrm{b}}$ and Viola I. Birss ${ }^{\mathrm{a}, *, \mathrm{z}}$ \\ ${ }^{a}$ Department of Chemistry, University of Calgary, Calgary, Alberta, Canada T2N 1N4
}

${ }^{b}$ Ballard Power Systems, Burnaby, British Columbia, Canada V5J $5 J 9$

Two Co oxide sol-derived catalysts, one based on ethylenediamine and one on 1,2-phenylenediamine, were synthesized and examined for their oxygen reduction reaction (ORR) behavior in $0.5 \mathrm{M} \mathrm{H}_{2} \mathrm{SO}_{4}$. Supporting the catalyst on carbon powder significantly improved the catalyst performance, while heat-treatment of the carbon-supported catalysts at $650-900^{\circ} \mathrm{C}$ for $2 \mathrm{~h}$ under nitrogen dramatically improved its activity and selectivity. The ORR activity was further improved by increasing the concentration of the $[\mathrm{Co}, \mathrm{N}, \mathrm{C}, \mathrm{O}]$-based catalyst on carbon powder to $4 \%(\mathrm{wt} \% \mathrm{Co} / \mathrm{C})$, employing the more aromatic 1,2-phenylenediamine ligand, and by using a ligand to Co ratio of 2:1.

(C) 2004 The Electrochemical Society. [DOI: 10.1149/1.1845089] All rights reserved.

Manuscript submitted July 3, 2004; revised manuscript received September 23, 2004. Available electronically December 20, 2004.

Proton exchange membrane (PEM) fuel cells demonstrate great promise as power sources of the future, combining a highly efficient conversion of chemical energy to electrical energy with pollutionfree operation. As fuel cells run on high purity $\mathrm{H}_{2}$ at low temperatures (below $100^{\circ} \mathrm{C}$ ), they produce no $\mathrm{NO}_{x}, \mathrm{SO}_{x}$, or $\mathrm{CO}_{2}$ and the only by-products of the fuel cell reaction are heat and water. However, the widespread commercialization of these fuel cells has been limited by a number of factors, including the difficulties in implementing a hydrogen infrastructure and the cost of the fuel cell.

The vast majority of the voltage, and therefore power, loss in the PEM fuel cell occurs at the cathode as, even when using costly Pt catalysts, the oxygen reduction reaction (ORR) is extremely sluggish. If an alternative catalyst could be found for the ORR, this would lower the cost significantly. The first indication that metallo $\left(\mathrm{N}_{4}\right)$ macrocycles could be used to catalyze the ORR was from work carried out by Jasinski in $1964,{ }^{1}$ when he reported that Co phthalocyanine $(\mathrm{CoPc})$ was an active ORR catalyst in alkaline solution. Unfortunately, the metallo $\left(\mathrm{N}_{4}\right)$ macrocycles are unstable in acidic solutions and it was not until the 1970s that it was determined that pyrolyzing the macrocycles at $500-1000^{\circ} \mathrm{C}$ in an inert atmosphere could greatly increase the stability of the catalyst materials. ${ }^{2}$ Heat-treatment was proposed to partially or completely break down the macrocyclic ring, resulting in new materials with activities that are influenced by the precursors employed. The active site for the ORR has not been determined, although a range of catalytic sites has been suggested and are the subject of much debate. ${ }^{3-6}$

It has more recently been demonstrated that a metallo $\left(\mathrm{N}_{4}\right)$ macrocyclic precursor is not necessary to observe catalytic ORR behavior and several syntheses have been attempted to create active ORR catalysts from simple $\mathrm{Fe}^{7-9}$ and Co-based precursors. ${ }^{10-13}$ In general, the syntheses that produce Co-based catalysts from simple precursors have not been as successful in producing equally active and selective ORR catalysts as those obtained through Fe-based routes. It is possible that Co requires either a redox active support that can act as an electron source, ${ }^{14}$ or a dimeric structure, ${ }^{5}$ to catalyze the desired four-electron reduction of $\mathrm{O}_{2}$ to $\mathrm{H}_{2} \mathrm{O}$.

Catalyst preparation techniques used by others have included sputter-coating $\mathrm{Co}$ and $\mathrm{C}$ together in a $\mathrm{N}_{2}$ atmosphere, ${ }^{10}$ incorporation of anionic Co species into an oxidized polypyrrole film, ${ }^{11}$ and heat-treating $\mathrm{Co}$ salts on carbon powder or carbon-coated Co nanocrystallites ${ }^{13}$ under flowing acetonitrile. ${ }^{12}$ However, the stability and activity of these materials for the ORR has not been competitive with that of $\mathrm{Pt}$, although their cost is significantly lower.

In our work, we have commenced with the synthesis of a Co oxide sol, following by the incorporation of $\mathrm{N}$-containing ligands

\footnotetext{
* Electrochemical Society Active Member

z E-mail: birss@ucalgary.ca
}

into the sol to produce a catalyst solution containing $\mathrm{Co}, \mathrm{N}, \mathrm{C}$, and $\mathrm{O}$. After adsorption onto carbon powder and an optional heattreatment in inert atmosphere, several active ORR catalysts have been produced. These catalysts are shown here to be very promising, out-performing the CoPc catalyst prepared as a benchmark in our laboratory.

\section{Experimental}

Synthesis of [Co, N, C, O]-based ORR catalysts.-4.4 g $\mathrm{Co}\left(\mathrm{NO}_{3}\right)_{2} \cdot 6 \mathrm{H}_{2} \mathrm{O}$ were dissolved in $15 \mathrm{~mL}$ of absolute ethanol, refluxed $\left(74^{\circ} \mathrm{C}\right)$ for $6 \mathrm{~h}$ and then stirred for $18 \mathrm{~h}$ at room temperature. Ethyl acetate $(15 \mathrm{~mL})$ was then added to prepare a $0.5 \mathrm{M}$ Co oxide sol. $^{16}$

A $10 \%(\mathrm{v} / \mathrm{v})$ ethylenediamine (en) (catalyst A) or $0.5 \mathrm{M} \mathrm{1,2-}$ phenylenediamine (phen) (catalyst B) solution was prepared in $50 / 50(\mathrm{v} / \mathrm{v})$ absolute ethanol:ethyl acetate, and then one molar equivalent of ligand was added dropwise over $6 \mathrm{~h}$ to a refluxing, stirred solution of the Co oxide sol. The white $\mathrm{NH}_{2} \mathrm{C}_{2} \mathrm{H}_{4} \mathrm{NH}_{3} \mathrm{NO}_{3}$ or $\mathrm{NH}_{2} \mathrm{C}_{6} \mathrm{H}_{4} \mathrm{NH}_{3} \mathrm{NO}_{3}$ precipitate that formed was filtered off. Up to 3.5 more equivalents of ligand (as a $10 \% \mathrm{v} / \mathrm{v}$ solution) were added over 3 days to the refluxing, stirred solution, along with water, as needed ( $c a$. $10 \%$ by volume), to prevent catalyst precipitation. Aliquots were removed from the refluxing solution to obtain the desired ligand ratios. The reaction was followed by UV-visible spectroscopy, confirming complexation of the ligands to the $\mathrm{Co}^{2+}$ center, as evidenced by a shift in $\lambda_{\max }$ from 515 to $470 \mathrm{~nm}$. The resulting solutions, ranging in concentration from 0.1 to $0.4 \mathrm{M}$ Co (phenbased catalysts) or 0.2 to $0.4 \mathrm{M}$ (en-based catalysts), depending on the ligand ratio, contained the $[\mathrm{Co}, \mathrm{N}, \mathrm{C}, \mathrm{O}]$-based catalyst, likely in a sol form.

Preparation of $[\mathrm{Co}, \mathrm{N}, \mathrm{C}, \mathrm{O}]$ catalyst-supported on $\mathrm{C}$ powder.-To adsorb the $\mathrm{Co}, \mathrm{N}, \mathrm{C}, \mathrm{O}$ sol onto carbon powder, the catalyst solutions (typically 0.2 to $0.9 \mathrm{~g}$ ) were refluxed with $0.25 \mathrm{~g}$ Vulcan XC-72R carbon powder for $12 \mathrm{~h}$, rinsed with absolute ethanol, and then filtered to prepare catalyst A and B. In the case of CoPc (Aldrich), $50 \mathrm{mg}$ of the solid was dissolved in $100 \mathrm{~mL}$ of THF and stirred with $0.25 \mathrm{~g}$ carbon powder under sonication for $2 \mathrm{~h}$, followed by a $12 \mathrm{~h}$ reflux. The powder was rinsed with hot and cold water and the rinsings were checked for any color. The catalyst powders were dried under vacuum overnight before testing.

Incipient impregnation ${ }^{17}$ of catalyst solution into the carbon powder was carried out to prepare catalyst B at higher concentrations. The catalyst solution (up to $8 \mathrm{~g}$ ) was applied by pipette to 0.25 g dry carbon powder and was allowed to evaporate to a dry powder before heat-treatment.

Catalyst heat-treatment.- - Heat-treatment of the carbon powdersupported catalysts was carried out prior to mixing with Nafion solution. The catalyst powder was slid into a quartz tube on a ceramic 
boat, remaining under a flow of $\mathrm{N}_{2}$ for at least $1 \mathrm{~h}$, and then was transferred into the preheated tube furnace, where the temperature was held at 650,700 , or $900^{\circ} \mathrm{C}$, depending on the experiment. The sample was heated for $2 \mathrm{~h}$ and then removed from the furnace and allowed to cool, all under a flow of $\mathrm{N}_{2}$.

ICP Analysis of heat-treated, carbon-supported catalysts.-A Thermo Jarrell Ash (model AtomScan 16) inductively coupled plasma atomic emission spectrometer (ICPAES) was used to determine the concentration of $\mathrm{Co}$ in the catalysts. The samples were prepared by dissolving the carbon-supported catalysts in refluxing $\mathrm{HCl}$ for $4 \mathrm{~h}$ and then filtering and diluting with deionized water.

Electrochemical assessment of catalyst behavior and determination of ORR activity.-A $7 \mathrm{~mm}$ diam glassy carbon (GC) rotating disk electrode (RDE) or a rotating ring disk electrode (RRDE), consisting of a $4.57 \mathrm{~mm}$ diam glassy carbon disc and a Pt ring (4.93 $\mathrm{mm}$ i.d., $5.38 \mathrm{~mm}$ o.d.), were used to measure the ORR activity of the various materials synthesized. A three-electrode electrochemical cell was used, containing a mesh counter electrode (Pt or Pt black) and a reversible hydrogen electrode (RHE) reference electrode. The $0.5 \mathrm{M} \mathrm{H}_{2} \mathrm{SO}_{4}$ electrolyte solution was purged with vigorously bubbling $\mathrm{N}_{2}$ or $\mathrm{O}_{2}$ and then kept under those gases at a flow rate of $36 \mathrm{~mL} / \mathrm{min}$ during the electrochemical measurements. The collection efficiency of the GC/Pt RRDE, calculated using the $\mathrm{Fe}(\mathrm{CN})_{6}^{4-} / \mathrm{Fe}(\mathrm{CN})_{6}^{3-}$ redox couple, was determined to be $18 \%$ on both smooth and carbon coated RRDEs at 100 to $4000 \mathrm{rpm}$. The carbon powder coated electrodes were employed to account for the increased surface roughness brought about by the catalyst coatings and the possible effect on the collection efficiency.

An 11\% Nafion solution (EW 1100) was diluted with absolute ethanol to give a $1 \%$ Nafion mixture. The $1 \%$ Nafion solution, used as a binder, was mixed with the carbon powder-supported catalysts in the appropriate ratio to give a 1:1 dry weight of catalyst to Nafion. The suspension was sonicated for 10-15 min before application to the electrode. The catalyst/Nafion mixture was applied using a micropipette $(6$ or $14 \mu \mathrm{L})$ to the center of the disc electrode to cover it fully, resulting in a loading of $0.6 \mathrm{mg} / \mathrm{cm}^{2}$ of carbon-supported catalyst. The electrode was then air dried at room temperature for $\sim 5$ min before drying with a heat gun for $1 \mathrm{~min}$.

Cyclic voltamograms (CVs) were first collected in $\mathrm{N}_{2}$-purged 0.5 $\mathrm{M} \mathrm{H}_{2} \mathrm{SO}_{4}$ at $100 \mathrm{mV} / \mathrm{s}$ for $20 \mathrm{~min}$ and then at $10 \mathrm{mV} / \mathrm{s}$ for $15 \mathrm{~min}$, both with no rotation, to obtain a baseline for comparison to the ORR data. The cell was then saturated with $\mathrm{O}_{2}$, as described above, and $\mathrm{CVs}$ were run at $10 \mathrm{mV} / \mathrm{s}$ and at different rotation rates $(250$ $2000 \mathrm{rpm}$ ), using a Pine analytical rotor (model ASR-2).

The RDE measurements were carried out with an EG\&G PARC 175 function generator in conjunction with a Hokuto Denko HA-301 potentiostat. The electrochemical data were recorded using Chart4 by PowerLab. For the RRDE measurements, a Pine AFCBP1 bipotentiostat was used in conjunction with Pine Chem 2.7.5.

All experiments reported here were run at room temperature $\left(20 \pm 3^{\circ} \mathrm{C}\right)$. RDE studies carried out at elevated temperatures $\left(67^{\circ} \mathrm{C}\right)$ to better simulate PEM fuel cell operating conditions showed a good correlation to the room temperature (RT) ORR activities of the catalysts.

\section{Results and Discussion}

Effect of heat-treatment of carbon powder-supported catalysts.-Direct application of non-carbon-supported catalysts to GC electrodes resulted in no ORR activity in acidic solutions, presumably due to the solubility of the [Co, N, C, O]-based materials in acid. Incorporation of Nafion into the catalyst or application of Nafion solution directly on top of a layer of dried catalyst was also attempted, but the observed $\mathrm{CV}$ response was also unstable and quickly deteriorated with time. Therefore, the ORR activity was only measured on carbon-supported catalysts. Table I shows the ORR activity of carbon-supported CoPc and catalyst A, both heattreated and non-heat-treated. It can be seen that, before heat-

\begin{tabular}{|c|c|c|c|c|}
\hline Catalyst $^{\mathrm{b}}$ & & $\begin{array}{c}\% \mathrm{O}_{2} \text { reduced } \\
\text { to } \mathrm{H}_{2} \mathrm{O}_{2} \\
\text { at } 0.2 \mathrm{~V}\end{array}$ & $\begin{array}{c}\text { Tafel slope } \\
\text { (mV/decade } \\
\text { of current) }\end{array}$ & $\begin{array}{l}\mathrm{V} \text { at which } \\
1.0 \mathrm{~mA} / \mathrm{cm}^{2} \\
\text { is passed }\end{array}$ \\
\hline \multirow[t]{2}{*}{ Non-heat-treated } & A & $28 \%(n=3.4)$ & $160-170$ & 0.12 \\
\hline & $\mathrm{CoPc}$ & $50 \%(n=3)$ & $220-230$ & 0.02 \\
\hline \multirow[t]{2}{*}{ Heat-treated } & A & $20 \%(n=3.6)$ & $115-125$ & 0.42 \\
\hline & $\mathrm{CoPc}$ & $50 \%(n=3)$ & $170-180$ & 0.16 \\
\hline
\end{tabular}

${ }^{\mathrm{a}} n$ is the number of electrons used to reduce one $\mathrm{O}_{2}$ molecule, as calculated from the relative magnitude of the ring and disk currents and the collection efficiency of the ring.

${ }^{\mathrm{b}}$ (GC/Pt ring disk, $0.5 \mathrm{M} \mathrm{H}_{2} \mathrm{SO}_{4}, 1000 \mathrm{rpm}, 10 \mathrm{mV} / \mathrm{s}$, Pt ring held at $1.3 \mathrm{~V}, \mathrm{RT})$

treatment, catalyst A has a somewhat higher activity and significally a lower Tafel slope. However, after heat-treatment, although the activities of both catalysts have improved notably, consistent with predictions, ${ }^{2,3,5,6,18}$ catalyst A was significantly more active than CoPc. ${ }^{19}$ Note that, in most cases, Tafel slopes above $120 \mathrm{mV}$ per decade of current are observed. Investigations currently underway suggest that the porous nature of the electrodes ${ }^{19}$ may be contributing to these higher than expected Tafel slopes.

The ORR can proceed either by the direct $4 \mathrm{e}$ - reduction reaction to $\mathrm{H}_{2} \mathrm{O}(n=4)$ or via the 2e- reduction to $\mathrm{H}_{2} \mathrm{O}_{2}(n=2)$, followed by reduction of $\mathrm{H}_{2} \mathrm{O}_{2}$ to water. Of the two mechanisms, the 2e- reduction to $\mathrm{H}_{2} \mathrm{O}_{2}$ is undesired, as it produces a lower voltage with less current (and therefore less power) and also as $\mathrm{H}_{2} \mathrm{O}_{2}$ is corrosive and can degrade the membrane, the catalyst, and other fuel cell components.

Figure 1 shows the ring (held at $1.3 \mathrm{~V}$ ) and the disk current for catalyst A, with and without heat-treatment, as well as for carbon powder alone (non heat-treated). As is summarized in Table I, catalyst $\mathrm{A}$ showed a decrease in $\mathrm{H}_{2} \mathrm{O}_{2}$ production to $20 \%(n=3.6)$ from $28 \%(n=3.4)$ of the total $\mathrm{O}_{2}$ produced before heat-treatment. The CoPc catalyst showed no change in $\mathrm{H}_{2} \mathrm{O}_{2}$ production with heattreatment, remaining at $50 \%(n=3)$, despite the increase in activity and a lowering of the Tafel slope. This decrease in the Tafel slope is likely indicative of a change in ORR mechanism, rather than arising from surface film porosity, in which case a lower activity

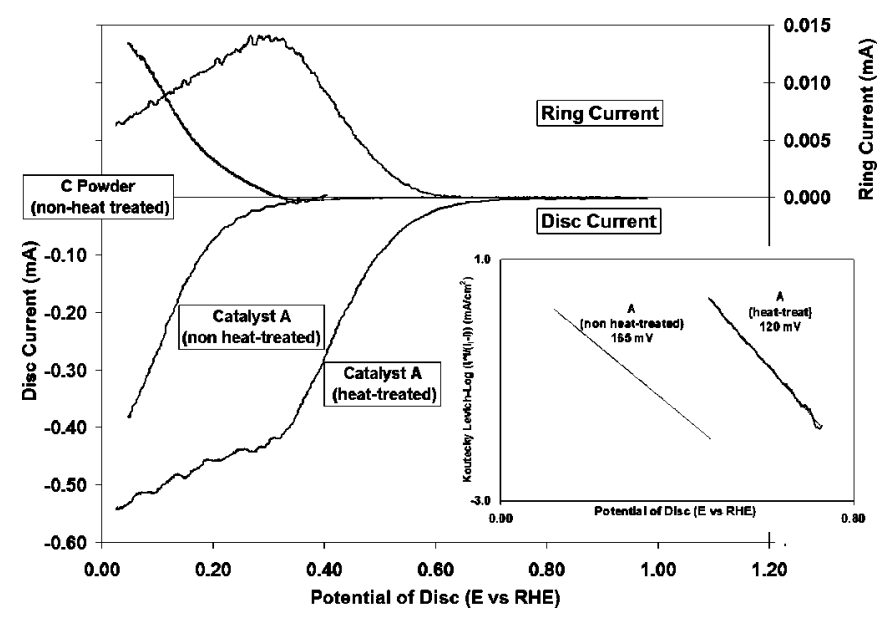

Figure 1. ORR at GC disk $\left(0.16 \mathrm{~cm}^{2}\right)$, coated with non-heat-treated carbon powder and catalyst $\mathrm{A}$, both non-heat-treated and heat-treated for $2 \mathrm{~h}$ at $650^{\circ} \mathrm{C}$, and $\mathrm{H}_{2} \mathrm{O}_{2}$ oxidation at Pt ring. Experiments carried out in oxygensaturated $0.5 \mathrm{M} \mathrm{H}_{2} \mathrm{SO}_{4}$ at $1000 \mathrm{rpm}, 10 \mathrm{mV} / \mathrm{s}$ and room temperature. Inset: Effect of heat-treatment of catalyst A on ORR activity (250 rpm) and Tafel slope. 


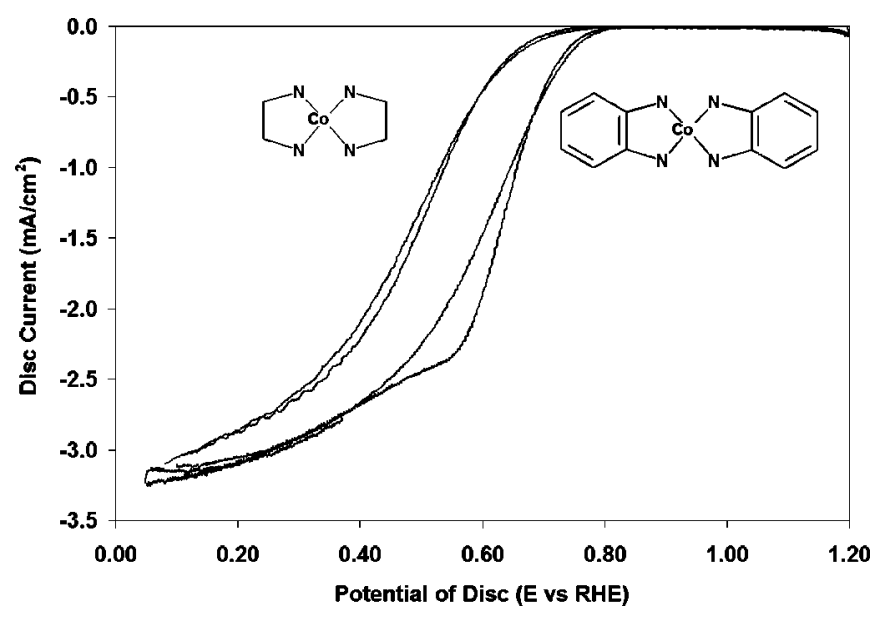

Figure 2. Comparison of ORR activity when ethylenediamine and 1,2phenylenediamine are used as ligands in the synthesis of catalysts $\mathrm{A}$ and $\mathrm{B}$, respectively. Ligand structures shown in figure depict precursor materials employed, not proposed heat-treated catalyst structures. Catalysts were heattreated for $2 \mathrm{~h}$ at $650^{\circ} \mathrm{C}$ and studied at GC disk $\left(0.38 \mathrm{~cm}^{2}\right)$ in $\mathrm{O}_{2}$-saturated $0.5 \mathrm{M} \mathrm{H}_{2} \mathrm{SO}_{4}$ at $1000 \mathrm{rpm}, 10 \mathrm{mV} / \mathrm{s}$ and room temperature.

would have been expected. C powder alone (heat-treated or not) has a very low ORR activity, similar to that of non-heat-treated catalyst A. Overall, heat-treatment dramatically improves the activity of catalyst $\mathrm{A}$, resulting in a more active and selective catalyst toward the ORR than CoPc. ${ }^{a}$

When other catalysts were prepared in our lab using similar methods as used for the synthesis of catalyst A, but with the omission of the Co oxide sol precursor in favor of only a Co salt $\left(\mathrm{Co}\left(\mathrm{NO}_{3}\right)_{2} \cdot 6 \mathrm{H}_{2} \mathrm{O}\right)$ solution, the resulting materials demonstrated little to no ORR activity. It is not known why the Co oxide sol is a necessary precursor for these catalysts. It is possible that the CoO-Co linkages hold the Co atoms the correct distance apart for each $\mathrm{O}_{2}$ molecule to interact simultaneously with two Co atoms, as is the case in the successful dimeric porphyrins. ${ }^{15}$ Alternatively, the oxide linkages of the Co oxide sol gel may also serve to better anchor the Co to the carbon support, allowing the site to serve as an electronic well to aid electron transfer to $\mathrm{O}_{2} \cdot{ }^{14}$ Whether the effect is a geometric or an electronic one, an active ORR catalyst can clearly be prepared from these simple precursors.

Optimization of ORR performance at [Co, N, C, O]-based catalysts.-To further improve the catalyst performance, phen was also investigated as a ligand precursor, as it is known that the ligand can significantly influence the ORR activity of the resulting heattreated catalysts. ${ }^{6,8}, 9$ Figure 2 shows that catalyst B, prepared with the phen ligand precursor, has a higher activity than the en-derived catalyst A, perhaps due to its aromatic nature. This may result in stronger bonds to the carbon support and therefore more facile electron transfer from the $\mathrm{Co}^{2+/ 3+}$ active metal site to $\mathrm{O}_{2}$. This is in agreement with results observed by Claude et $a .^{6}{ }^{6}$ where it was observed that heat-treated CoPc had a higher activity than Co cyclam. These results are also consistent with the data obtained by Bron et al., showing that when heat-treated under $\mathrm{Ar}$ or $\mathrm{NH}_{3}$, catalysts derived from $\mathrm{Fe}$ phenanthroline were more active than those from $\mathrm{FeSO}_{4}, \mathrm{Fe}(\mathrm{CN})_{6}^{4-}$, or $\mathrm{Fe}\left(\right.$ bipyridyl). ${ }^{8,9}$

The effect of changing the ligand ratio was also investigated and the optimum ORR activity for catalyst $\mathrm{B}$ was found to be a 2:1 ligand to Co (Fig. 3), corresponding to a ratio of $4 \mathrm{~N}$ to $1 \mathrm{Co}$. The $\mathrm{CoN}_{4}$ moiety was expected to be very active, as it is the same ratio

${ }^{a}$ We recognize that CoPc has previously been reported with a higher ORR activity than shown in Table I [e.g., E. Claude, T. Adduo, J. Latour, and P. Aldebert, J. Appl. Electrochem., 28, 57 (1998)], but this is the highest activity we were able to obtain using a similar approach as for our catalysts.

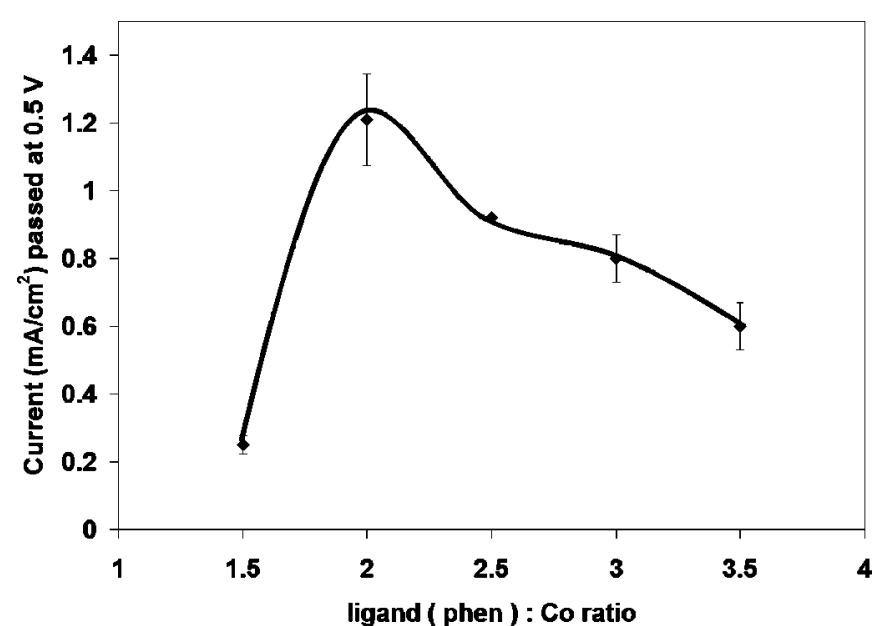

Figure 3. Effect of phen ligand to Co ratio of catalyst $\mathrm{B}$ on ORR activity of heat-treated catalyst $\left(2 \mathrm{~h}\right.$ at $\left.650^{\circ} \mathrm{C}\right)$ at $\mathrm{GC}$ disc in $\mathrm{O}_{2}$-saturated $0.5 \mathrm{M} \mathrm{H}_{2} \mathrm{SO}_{4}$ at $1000 \mathrm{rpm}$ and $10 \mathrm{mV} / \mathrm{s}$.

as in the $\mathrm{CoN}_{4}$ macrocyclic materials. Increasing the ratio beyond this may cause additional ligands to bind to the Co, thus blocking $\mathrm{O}_{2}$ adsorption sites and resulting in a lower ORR activity. Although not shown in Fig. 3, the en-based catalysts also show an optimum performance at a ligand to Co ratio of 2:1.

The ORR activity was also improved by optimizing the concentration of the $[\mathrm{Co}, \mathrm{N}, \mathrm{C}, \mathrm{O}]$-based catalyst on the carbon powder support. As can be seen in Fig. 4, there is an increase in ORR activity up to $4 \%$ Co on carbon powder (wt/wt). Above this, the activity drops, likely due to the formation of metallic Co, which occurs at high catalyst (low carbon powder) loadings, as observed by X-ray photoelectron spectroscopy and scanning electron microscopy ${ }^{19}$ analyses. Metallic Co present on a carbon support has been previously reported to be inactive toward the ORR. ${ }^{1}$

While we are quite certain that metallic Co is not active toward the ORR, the active site has been more difficult to elucidate. The present research suggests the involvement of at least two active sites, one formed at lower temperatures $\left(\leqslant 500^{\circ} \mathrm{C}\right)$ and the other formed at higher temperatures $\left(\geqslant 500^{\circ} \mathrm{C}\right)$. A more detailed analysis

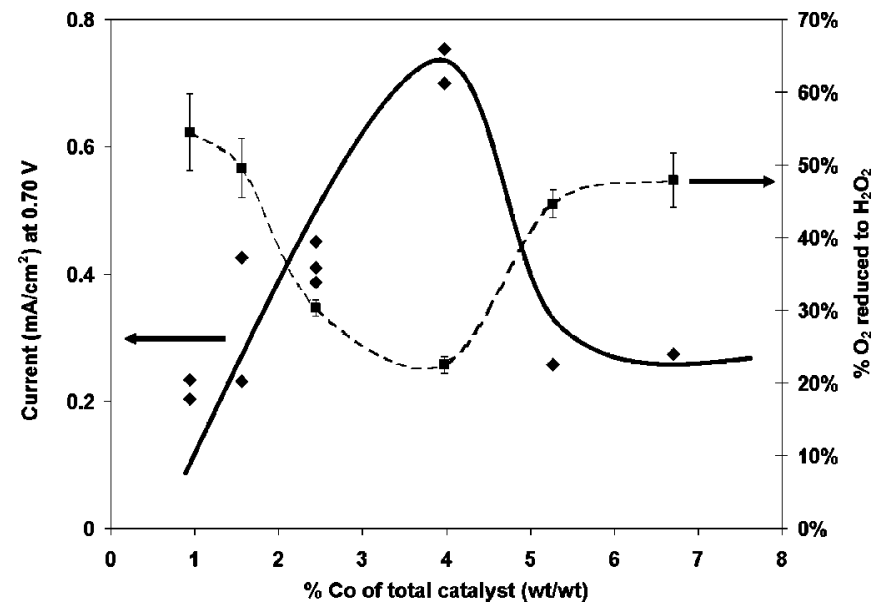

Figure 4. Effect of amount of catalyst B (phen:Co ratio is 2.5:1) supported on carbon powder, on ORR activity and selectivity. Catalysts were heattreated at $900^{\circ} \mathrm{C}$ for $2 \mathrm{~h}$ and electrochemistry was carried out at $\mathrm{Pt} / \mathrm{GC}$ ring-disc electrode in $\mathrm{O}_{2}$-saturated $0.5 \mathrm{M} \mathrm{H}_{2} \mathrm{SO}_{4}$ at $1000 \mathrm{rpm}$ and $10 \mathrm{mV} / \mathrm{s}$. 
of the characterization of these catalysts in relation to these two proposed active sites, is currently in preparation. ${ }^{20}$

In terms of longer term performance, while both the en- and phen-based catalysts are very stable at open circuit in $0.5 \mathrm{M}$ sulfuric acid, some loss of potential (2-10\%) was observed over $\sim 20 \mathrm{~h}$ at applied current densities in the range of $0.5-1 \mathrm{~mA} / \mathrm{cm}^{2}$. The stability of these catalysts will be discussed in greater detail in later published work.

\section{Conclusion}

Two Co oxide sol derived catalysts, A (based on ethylenediamine, en) and B (based on 1,2-phenylenediamine, phen), were synthesized and tested for their oxygen reduction reaction (ORR) activity and selectivity in $0.5 \mathrm{M} \mathrm{H}_{2} \mathrm{SO}_{4}$. The performance of these catalysts, both in the heat-treated and non-heat-treated condition, were bench-marked against carbon-supported Co phthalocyanine $(\mathrm{CoPc})$, prepared in our laboratory. The pure (non-carbon-supported) catalysts showed no measurable ORR activity, perhaps due to their lack of stability in the acidic medium. Supporting the catalyst on carbon powder significantly improved the catalyst stability and activity, although without heat-treatment, the activity was still very poor, only slightly more active than carbon powder alone.

Catalyst (plus carbon powder) heat-treatment, carried out at 650 or $700^{\circ} \mathrm{C}$ for $2 \mathrm{~h}$ under $\mathrm{N}_{2}$, dramatically improved its activity and also improved the selectivity. It is especially promising that the mechanism of catalyst A (heat-treated) was more efficient that that of CoPc (heat-treated), with an apparent number of electrons transferred to $\mathrm{O}_{2}, n$, of 3.6, compared to an $n$ value of 3 for CoPc.

It was found to be possible to further improve the ORR activity by increasing the concentration of the [Co, N, C, O]-based catalyst on carbon powder, with the optimum value being $4 \%(\mathrm{Co} / \mathrm{C} \mathrm{wt} / \mathrm{wt})$. Further, a notable improvement in the ORR rates was seen when the more aromatic phen ligand was employed, vs. en. Also, the highest ORR activity was seen for a ligand to Co ratio of 2, i.e., a ratio of 4 $\mathrm{N}$ per Co. To our knowledge, our Co-based catalysts, based on simple precursors, are more active toward the ORR than any other similar Co-based materials, based on simple precursors, discussed to date in the literature. ${ }^{10-13}$

\section{Acknowledgments}

The authors thank the Natural Sciences and Engineering Research Council of Canada and Ballard Power Systems for the overall support of this work and also for the post-graduate scholarship support of AHCS.

The University of Calgary assisted in meeting the publication costs of this article.

\section{References}

1. R. Jasinski, Nature (London), 201, 1212 (1964).

2. H. Jahnke, M. Schönborn, and G. Zimmerman, Top. Curr. Chem., 61, 133 (1976).

3. M. Gokita, M. Yuasa, and I. Sekine, J. Electrochem. Soc., 145, 815 (1998).

4. M. Tsionsky and O. Lev, J. Electrochem. Soc., 142, 2132 (1995).

5. O. Contamin, C. Debiemme-Chouvy, M. Savy, and G. Scarbeck, Electrochim. Acta, 45, 721 (1999).

6. E. Claude, T. Adduo, J. Latour, and P. Aldebert, J. Appl. Electrochem., 28, 57 (1998).

7. (a) M. Lefèvre, J. Dodelet, and P. Bertrand, J. Phys. Chem., 104, 11238 (2000); (b) M. Lefèvre and J. Dodelet, Electrochim. Acta, 48, 2749G (2003); (c) Lalande, R. Cote, D. Guay, J. Dodelet, L. Weng, and P. Bertrand, Electrochim. Acta, 42, 1379 (1997).

8. M. Bron, J. Radnik, M. Fieber-Erdmann, P. Bogdanoff, and S. Fiechter, J. Electroanal. Chem., 535, 113 (2002).

9. M. Bron, S. Fiechter, M. Hilgendorff, and P. Bogdanoff, J. Appl. Electrochem., 32, 311 (2002).

10. (a) C. Deng and M. Digman, J. Electrochem. Soc., 145, 3507 (1998); (b) C. Deng and M. Digman, J. Electrochem. Soc., 145, 3513 (1998).

11. W. Seeliger and A. Hamnett, Electrochim. Acta, 37, 763 (1992).

12. R. Cote, G. Lalande, G. Faubert, D. Guay, J. Dodelet, and G. Denes, J. New Mater. Electrochem. Syst., 1, 7 (1998).

13. G. Lalande, G. Guay, J. Dodelet, S. Majetich, and M. McHenry, Chem. Mater., 9, 784 (1997).

14. (a) C. Shi and F. Anson, J. Am. Chem. Soc., 113, 9564 (1991); (b) R. Kingsborough and T. Swager, Chem. Mater., 12, 872 (2000).

15. (a) P. Collman, F. Anson, C. Bencosme, R. Durand, and R. Kreh, J. Am. Chem. Soc., 105, 3699 (1983); (b) C. Li, I. Abdalhuhdi, C. Chang, and F. Anson, J. Phys. Chem., 91, 1158 (1987); (c) R. Durand, C. Bencosme, J. Collman, and F. Anson, J. Am. Chem. Soc., 105, 2710 (1983).

16. F. Meaner and N. Lynam, U.S. Pat. 4,959,247 (1990).

17. (a) A. Guerrero-Ruiz, P. Badenes, and I. Rodriguez-Ramos, Appl. Catal., A, 173, 313 (1998); (b) S. T. Srinivas, B. M. Reddy, P. K. Rao, and A. P. Rao, in Recent Developments of Catalysis: Theory and Practice, B. Wiswanathan and C. N. Pillai, Editors, Technip, Paris, France (1991).

18. H. Alt, H. Binder, and G. Sanstede, J. Catal., 28, 8 (1973).

19. (a) B. Tilak, R. Yeo, and S. Srinivasan, in Comprehensive Treatise of Electrochemistry: Electrochemical Energy Conversion and Storage, p. 39, Plenum Press, New York (1981); (b) J. Bockris and S. Srinivasan, Fuel Cells: Their Electrochemistry, p. 230, McGraw-Hill, New York (1969); (c) R. de Levie, Advances in Electrochemistry and Electrochemical Engineering, p. 329, John Wiley \& Sons, New York (1999).

20. V. Birss, A. Sirk, and S. Campbell, In preparation. 